\title{
Microassay for prostatic androgen receptors correlated with quantitative histological assessment
}

\author{
S M WIDDOWSON, J L OSTROWSKI, V J M DANGERFIELD, S C HARRIS, \\ P M INGLETON, J C E UNDERWOOD, J L WILLIAMS, * M A PARSONS Department of \\ Pathology, University of Sheffield Medical School, and the *Department of Urology, Royal Hallamshire \\ Hospital, Sheffield
}

SUMMARY A new microassay in which cryostat sections of prostate tissue were used to provide the source of soluble androgen receptor for biochemical assay, was devised using an isoelectric focusing method, with $\left[{ }^{3} \mathrm{H}\right]$-mibolerone as the androgenic radioligand. Adjacent cryostat sections from the same tissue block were stained for diagnostic and quantitative histological assessment. The assay was used to illustrate variations in tissue androgen receptor concentration for correlation with epithelial cell content in benign prostate hyperplasia and prostatic cancer, and to show the effects of androgen receptor concentration of resection of prostatic tissue by electroresection.

The results indicate that the heat in electroresection renders prostatic tissue unsuitable for androgen receptor assays, and suggest that knowledge of the cellular composition of carcinomatous prostates may be of importance in the full assessment of androgen receptor assay results.

This method incorporates both a biochemical assay and histological assessment of the assayed tissue on near-facsimile sections, an advantage over conventional biochemical assays.

The dependence of the prostate on hormonal stimulation for its growth and development has been known for a long time, but it was not until 1941 that Huggins and Hodges found that androgen injection in patients with prostatic carcinoma had a harmful effect and that oestrogen injection or castration were beneficial.' Almost $75 \%$ of patients with prostatic carcinoma present with inoperable metastatic tumours, ${ }^{2}$ and treatment with oestrogen or castration produced evident improvement in $60-80 \%$ of these patients. ${ }^{2-4}$ Some patients, however, subsequently relapse and prove insensitive to further hormonal treatment, ${ }^{5}$ leaving only the options of cytotoxic drugs or radiotherapy for the further management of the tumour.

Androgen receptor concentrations have begun to be assayed in prostatic carcinoma to determine which tumours (with high androgen receptor concentrations) are most likely to respond to hormonal treatment. Several reports have shown a correlation between androgen receptor concentration and a favourable clinical response to endocrine treatment, ${ }^{6-8}$ but this is not a universal finding. ${ }^{910}$ The importance of previous studies is difficult to assess, however, because of the variety of assay methods used and questionable tissue sampling techniques with no histological verification of the presence of tumour in the assayed sample.

Most androgen receptor assays are performed on homogenised prostatic tissue samples, but it is quesAccepted for publication 4 August 1988 tionable whether this technique is valid for tissue such as the prostate where there may be considerable variation in the composition of cellular elements, with possible local variations in androgen receptor concentration. Most prostatic surgery is done by transurethral electroresection (TURP) with possible destruction of heat-labile androgen receptor. Some authors have assayed TURP specimens without reservations, ${ }^{911}$ some have considered them unreliable, ${ }^{12-15}$ and others have compromised by selecting only the largest portions and removing charred areas. $^{16-18}$

To address some of these problems we developed a novel androgen receptor microassay, ${ }^{19}$ modified from our cryostat section methods for oestrogen and progesterone receptors. ${ }^{2021}$ In this assay the tissue diagnosis, cellular composition, and androgen receptor concentration are all determined in near-facsimile cryostat sections of prostatic tissue.

\section{Material and methods}

Fresh prostatic tissue was obtained from 18 patients with benign prostatic hyperplasia: nine by retropubic prostatectomy (RPP), nine by transurethral resection (TURP), and nine patients who underwent TURP for prostatic adenocarcinoma. Retropubic prostatectomy specimens were cut into pieces (about 5-10 $\times 5 \mathrm{~mm}$ ); TURP specimens greater than $3 \mathrm{~mm}$ in diameter with little obvious diathermy damage were selected. 
Samples were wrapped in aluminium foil, snap frozen, and stored at $-70^{\circ} \mathrm{C}$ until assayed. Remaining prostatic tissue was fixed in formalin, extensively sampled, and conventionally stained with haematoxylin and eosin.

Two consecutive adjacent cryostat sections of frozen prostatic tissue were cut at $6 \mu \mathrm{m}$, mounted on glass slides, and stained with haematoxylin and eosin. A further four to six consecutive sections were cut at $\mathbf{4 0}$ $\mu \mathrm{m}$, collected on a small glass coverslip, and transferred into a $70 \times 9 \mathrm{~mm}$ plastic tube containing $200 \mu \mathrm{l}$ of Tris-edetic acid (ET) buffer (10 mM Tris; $1.5 \mathrm{mM}$ disodium edetic acid; $0.05 \%$ bovine serum albumin; $0.02 \%$ sodium azide, $\mathrm{pH} 7 \cdot 4$ ). All assays were performed in duplicate.

The androgen receptor microassay technique was based on the isoelectric focusing androgen receptor assay of Auf and Ghanadian, ${ }^{22}$ and our oestrogen and progesterone receptor assays. ${ }^{2021}$ Coverslips with adherent cryostat sections were gently crushed with a metal rod in $200 \mu$ l of ET buffer in the assay tube at $4^{\circ} \mathrm{C}$. To each tube was added a further $200 \mu \mathrm{l}$ of ET buffer containing the synthetic androgenic radioligand $\left[{ }^{3} \mathrm{H}\right]$-mibolerone (7-alpha-17-alphadimethyl [17alpha-methyl ${ }^{3} \mathrm{H}$ ] 19-nortestosterone) ${ }^{23-25}$ (Amersham International plc) at $1 \times 10^{-8} \mathrm{M}$ (final concentration of $\left[{ }^{3} \mathrm{H}\right]$-mibolerone of $5 \times 10^{-9} \mathrm{M}$ ), and $1 \times 10^{-6} \mathrm{M}$ ORG2058 (16 $\alpha$-ethyl-21-hydroxy-19 norpregn-4-en-3, 20 dione) to prevent the binding of $\left[{ }^{3} \mathrm{H}\right]$-mibolerone to progesterone receptor.

After overnight incubation at $4^{\circ} \mathrm{C}$ and centrifugation at $1000 \times g$ for 25 minutes $50 \mu$ l of supernatant cytosol was assayed for protein by the Coomassie blue method of Bradford ${ }^{25}$ using bovine serum albumin as the protein standard. The remaining cytosol was treated for five minutes with $200 \mu \mathrm{l}$ dextran-coated charcoal $(1 \% \mathrm{w} / \mathrm{v})$ to remove unbound radioligand. After centrifugation $100 \mu \mathrm{l}$ aliquots of the supernatant were subjected to isoelectric focusing.

The time taken for androgen receptor to diffuse from cryostat sections was determined by taking six consecutive groups of sections from one prostate and allowing them to stand, with occasional agitation, in $300 \mu \mathrm{l}$ of ET buffer on ice for five, 10, 20, 35, 65 or 125 minutes (in duplicate). Immediately after centrifugation $200 \mu \mathrm{l}$ of supernatant was aspirated from each tube and assi.yed for androgen receptor as described above.

The time taken for $\left[{ }^{3} \mathrm{H}\right]$-mibolerone to reach equilibrium binding to androgen receptor already in solution was determined separately. Samples of pooled supernatants from cryostat sections, kept at $4^{\circ} \mathrm{C}$ in ET buffer for one hour after centrifugation, were incubated with $\left[{ }^{3} \mathrm{H}\right]$-mibolerone for two, four, eight, 14 or 21 hours before androgen receptor binding was assayed as below.

To investigate the specificity of binding of

mibolerone to cytosolic androgen receptor pooled cytosols were incubated with $5 \times 10^{-9} \mathrm{M}\left[{ }^{3} \mathrm{H}\right]-$ mibolerone either alone or in the presence of a 100 fold molar excess of mibolerone, testosterone, progesterone, ORG-2058, diethylstilboestrol or hydrocortisone (in the absence of the 1000 -fold molar excess of ORG-2058 routinely used in the assay to block the binding of mibolerone to progesterone receptor). After incubation the receptor-bound $\left[{ }^{3} \mathrm{H}\right]$-mibolerone was assayed as below.

Supernatant samples $(100 \mu \mathrm{l})$ from the incubation of cryostat sections with $\left[{ }^{3} \mathrm{H}\right]$-mibolerone were subjected to isoelectric focusing in a thin layer polyacrylamide gel $(245 \times 110 \times 2 \mathrm{~mm} ; 2.4 \%$ (weight/volume) ampholine, pH 3.5-9.5; (Pharmacia Ltd) under conditions similar to those used by Gustafsson et al ${ }^{27}$ At the end of the focusing period gel slices $(5 \mathrm{~mm})$ were incubated in $4 \mathrm{ml}$ of $\mathrm{HP} / \mathrm{b}$ scintillant (Beckman) at $50^{\circ} \mathrm{C}$ for one hour, with gentle agitation.

The radioactivity of each phial was measured by liquid scintillation counting, with quench monitoring by $\mathrm{H}$ number (external standard Compton edge monitoring with ${ }^{137}$ Caesium), using a Beckman LS1801 automated liquid scintillation spectrometer. A histogram of radioactivity against gel slice number was plotted for each sample and the cumulative height

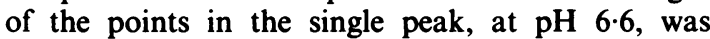
measured above the diagrammatic baseline. The amount of bound $\left[{ }^{3} \mathrm{H}\right]$-mibolerone represented in the peak was computed and related to the quantified cytosol protein concentration. Results were finally expressed in $\mathrm{fmol} / \mathrm{mg}$ of cytosol protein.

A measurement of the affinity of binding of $\left[{ }^{3} \mathrm{H}\right]-$ mibolerone to soluble androgen receptor was performed on pooled cytosol from cryostat sections from a piece of prostatic tissue, as previously described for oestrogen receptor and progesterone receptor binding. ${ }^{20} 21$ The concentration of bound radioligand in the reaction was calculated and plotted against the bound:free ratio for each concentration. ${ }^{28} 29$

The cellularity of the assayed cryostat sections with regard to their epithelial or neoplastic cell content was estimated by point counting ${ }^{2030}$ on the adjacent sections stained with haematoxylin and eosin for light microscopy. The fraction of points coincident with epithelial or tumour cells was recorded for each field until the entire section had been covered. The mean value was calculated and the result expressed as a percentage estimate of the sectional area occupied by epithelium or tumour.

"Crude" androgen receptor concentrations were "corrected" for epithelial cellularity using the formula:

"corrected" androgen receptor =

"crude" androgen receptor $\times 100$ cellularity $(\%)$ 
324

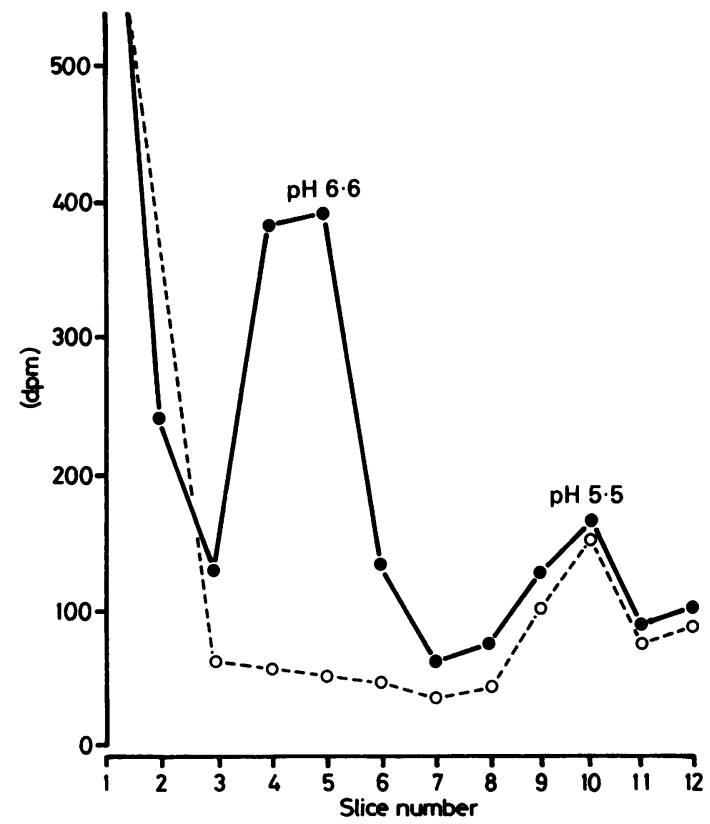

Fig 1 Isoelectric focusing profile of $5 \times 10^{-9} \mathrm{M}^{3} \mathrm{H}$ mibolerone binding to prostatic cytosol, in the absence $(0-0)$ and presence $(O---O)$ of a coincubated 100-fold molar excess of unlabelled mibolerone. Peak at pH 6.6 represents androgen receptor protein, and peak at pH 5.5 is sex hormone binding globulin.

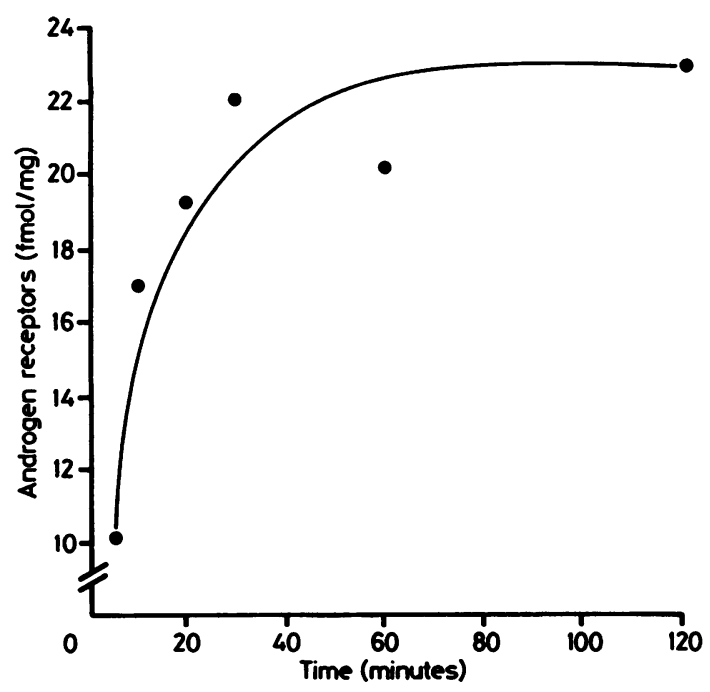

Fig 2 Diffusion of androgen receptor into aqueous buffer from cryostat sections of prostatic carcinoma, determined by ${ }^{3} \mathrm{H}$-mibolerone binding. Most androgen receptor diffusion occurs in the first 60 minutes.
Widdowson, Ostrowski, Dangerfield, et al

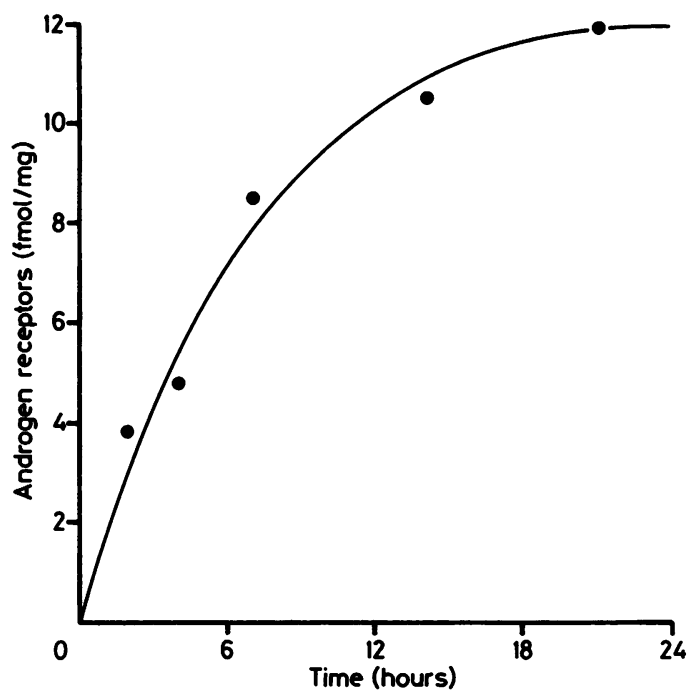

Fig 3 Equilibration of ${ }^{3} \mathrm{H}$-mibolerone binding to androgen receptor in supernatants of cryostat sections of prostatic carcinoma. Equilibration occurs at 16-20 hours.

\section{Results}

\section{HISTOLOGY}

Benign prostatic hyperplasia was confirmed on the cryostat and paraffin wax sections from nine retropubic and nine TURP specimens. Prostatic adenocarcinoma was present in only six of the nine cryostat sections of tissue selected for androgen receptor assay from the patients with prostatic cancer, but carcinoma was present in paraffin wax sections from all nine of these prostates.

\section{ANDROGEN RECEPTOR CHARACTERISTICS}

Two peaks of androgenic binding of $\left[{ }^{3} \mathrm{H}\right]$-mibolerone to prostatic cytosol were detected after isoelectric focusing (fig 1). The peak at $\mathrm{pH} 6.6$ represents high affinity, low capacity androgen receptor binding, as

Table 1 Androgen receptor binding to $5 \times 10^{-9}\left[{ }^{3} \mathrm{H}\right]$ mibolerone, in presence of steroid competitors at $5 \times 10^{-7} \mathrm{M}$ concentrations, assayed by isoelectric focusing method

\begin{tabular}{|c|c|}
\hline Competitor & $\begin{array}{l}\left.{ }_{(}^{3} \mathrm{H}\right] \text {-mibolerone binding } \\
\text { (percent uncompeted value }\end{array}$ \\
\hline $\begin{array}{l}\text { None } \\
\text { Mibolerone } \\
\text { Testosterone } \\
\text { ORG-2058 } \\
\text { Progesterone } \\
\text { Diethylstilboestrol } \\
\text { Hydrocortisone }\end{array}$ & $\begin{array}{l}100 \\
14 \cdot 7 \\
33 \cdot 7 \\
87 \cdot 1 \\
65 \cdot 1 \\
103 \\
100\end{array}$ \\
\hline
\end{tabular}




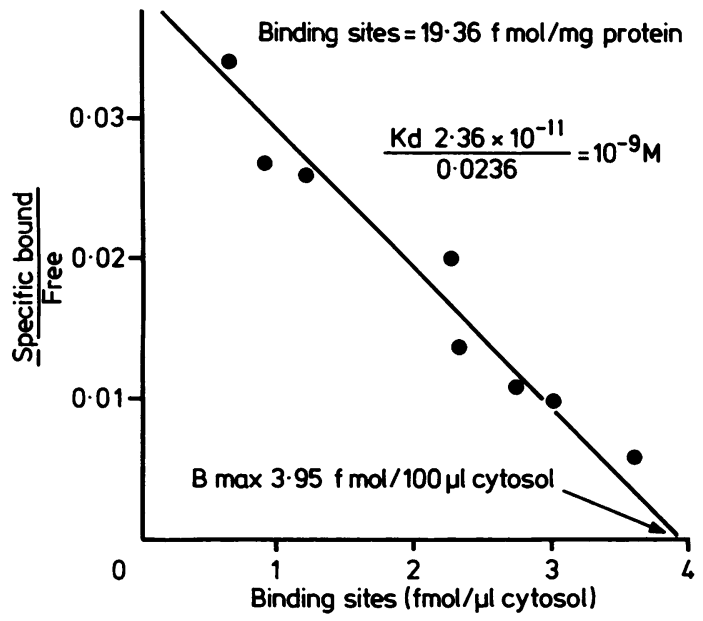

Fig 4 Scatchard analysis of affinity of binding of ${ }^{3} \mathrm{H}$ mibolerone to cytosol from cryostat sections of prostatic carcinoma. Straight line indicates single class of binding protein, the high affinity androgen receptor.
Table 2 Benign prostatic hyperplasia:androgen receptor concentrations (fmol/mg $\pm S E M$ ) in retropubic and transurethral resection specimens $\dagger$

\begin{tabular}{|c|c|c|}
\hline & "Crude" & "Corrected" \\
\hline $\begin{array}{l}\text { Retropubic }(\mathrm{n}=9) \\
\text { Transurethral }(\mathrm{n}=9)\end{array}$ & $\begin{array}{l}7.6(0.97)^{*} \\
3.4(0.68)^{*}\end{array}$ & $\begin{array}{c}85.6(20) \\
123.8(97 \cdot 5)\end{array}$ \\
\hline
\end{tabular}

${ }^{*} \mathrm{p}<0.01$.

†The effect of "correcting" and "crude" androgen receptor values for epithelial cellularity is shown.

described by Auf and Ghanadian. ${ }^{22}$ The second peak, at $\mathrm{pH} 5.5$, represents sex hormone binding globulin. ${ }^{2231}$

\section{DIFFUSION AND BINDING STUDIES}

Fig 2 shows that most of the androgen receptor had diffused from the cryostat sections into buffer in the first hour, as is the case for oestrogen receptor ${ }^{20}$ and progesterone receptor. ${ }^{21}$ Once in the supernatant, androgen receptor bound relatively slowly to $\left[{ }^{3} \mathrm{H}\right]-$

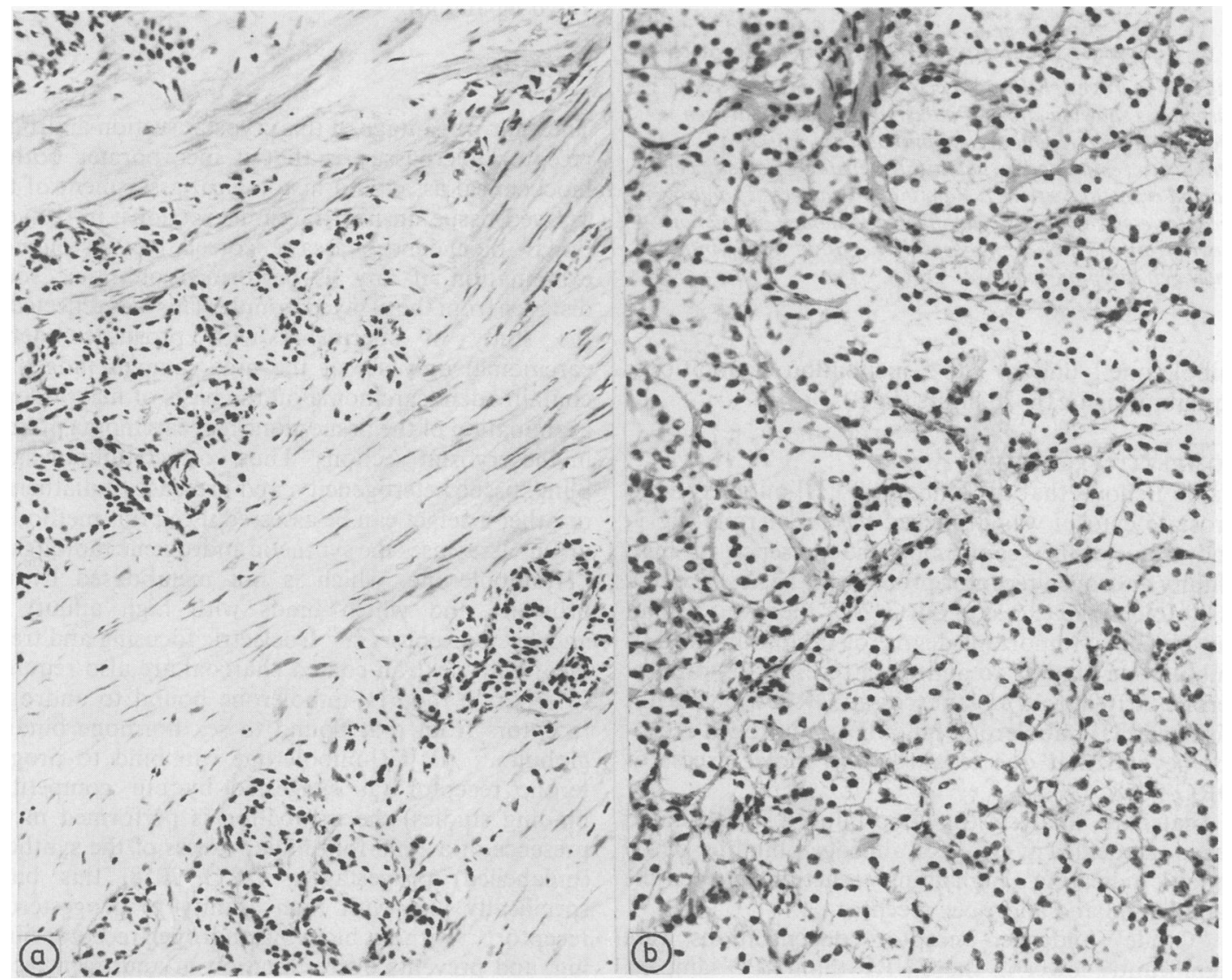

Fig 5 Two well differentiated prostate adenocarcinomas, both with a microacinar growth pattern. Tumour a has a low epithelial cellularity (17\%) and prominent stroma; tumour b has little stroma and a high epithelial cellularity (98\%). (Haematoxylin and eosin.) 


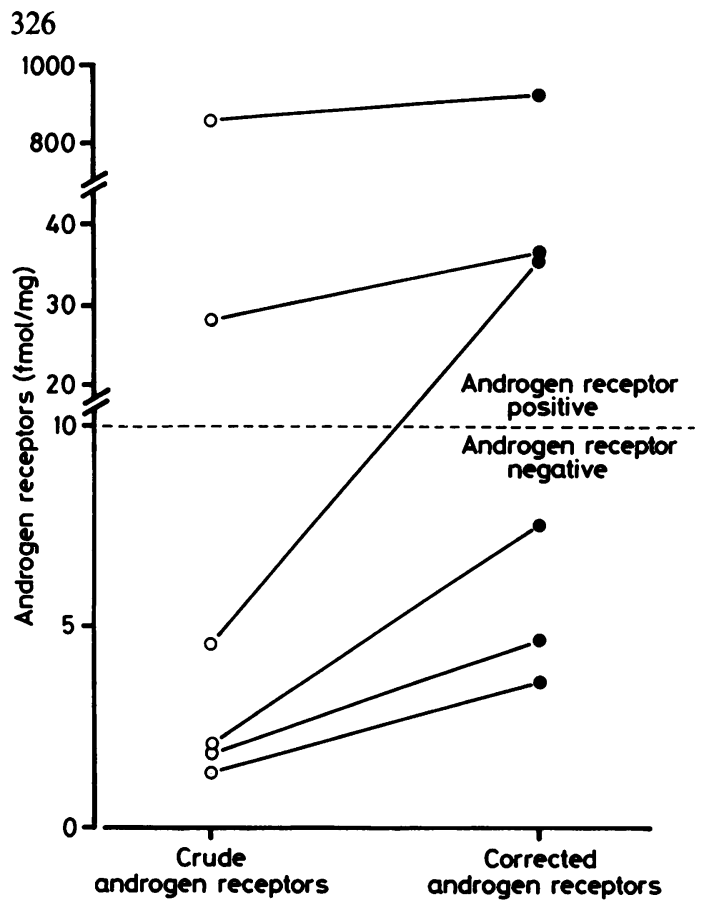

Fig 6 Androgen receptor in cryostat sections of prostatic carcinoma showing effect of adjusting "crude" androgen receptor concentration to take into account epithelial cellularity (estimated by quantitative histology on adjacent stained cryostat sections). Ranking of "corrected" androgen receptor concentrations is unaffected, although one tumour moves from the androgen receptor "negative" group into the androgen receptor "positive" group.

mibolerone under our incubation conditions, equilibrating in 16-20 hours (fig 3).

\section{COMPETITIVE BINDING}

Table 1 shows that the binding of $\left[{ }^{3} \mathrm{H}\right]$-mibolerone to prostate cytosol was displaced by mibolerone (fig 1) and testosterone, confirming the presence of high affinity androgen receptor protein. In the absence of a 1000-fold molar excess of ORG-2058 there was a small but clinically important degree of inhibition of $\left[{ }^{3} \mathrm{H}\right]-$ mibolerone binding to androgen receptor by progesterone. A 1000-fold molar excess of ORG-2058 did not displace $\left[{ }^{3} \mathrm{H}\right]$-mibolerone binding to androgen receptor beyond that due to a 100 -fold molar excess of ORG-2058.

Scatchard analysis (fig 4) produced a calculated reaction coefficient $(\mathrm{Kd})$ for androgen binding of 1.0 $\mathrm{nmol} / \mathrm{l}$, indicating a high affinity reaction between the radioligand and androgen receptor.

"Crude" androgen receptor concentrations were significantly lower in the TURP than RPP samples, but there were no significant differences when
Widdowson, Ostrowski, Dangerfield, et al

androgen receptor concentrations were "corrected" for epithelial cellularity (table 2).

\section{ANDROGEN RECEPTORS IN PROSTATIC CARCINOMA}

In the six RPP samples containing prostatic adenocarcinoma the mean "crude" androgen receptor concentration was 151 (\% range $1.4-867) \mathrm{fmol} / \mathrm{mg}$ cytosol protein. Androgen receptor concentration "corrected" for epithelial cellularity was $166 \cdot 6$, range $3 \cdot 5-$ $912.7 \mathrm{fmol} / \mathrm{mg}$ cytosol protein. The epithelial cellularity within prostatic adenocarcinomas was variable both within and between individual tumours (fig 5). "Correction" for epithelial cellularity did not change the ranking of androgen receptor concentration results in this small number of samples, but one tumour changed from being "androgen receptor negative" (androgen receptor of $<10 \mathrm{fmol} / \mathrm{mg}$ cytosol protein) to "androgen receptor positive" as a result of this "correction" (fig 6).

The mean protein concentration in prostatic cytosol preparations was $117.9 \mu \mathrm{g} / 100 \mu \mathrm{l}$, range $40.8-$ $183.0 \mu \mathrm{g} / 100 \mu \mathrm{l})$.

\section{Discussion}

The main advantage of this cryostat section androgen receptor microassay is that it incorporates both a biochemical assay and histological assessment of the assayed tissue on near-facsimile sections; in conventional biochemical assays correlative histological examination, if any, is performed on tissue some distance from the assayed sample. This was reflected in the study of specimens with prostatic adenocarcinoma; only six of the nine samples judged to contain adenocarcinoma on the basis of macroscopic examination of the tissue alone had carcinoma present in the cryostat sections. Thus correct tumour sampling, tissue heterogeneity, and presence of diathermy or other artefact can be assessed using this method.

Our assay uses the synthetic androgenic radioligand $\left[{ }^{3} \mathrm{H}\right]$-mibolerone, which is not metabolised by the prostate, and which binds with high affinity to androgen receptors. ${ }^{23-25}$ Isoelectric focusing and treatment with dextran-coated charcoal are also required to separate the $\left[{ }^{3} \mathrm{H}\right]$-mibolerone bound to androgen receptors from that bound to sex hormone binding globulin. ${ }^{22}$ As $\left[{ }^{3} \mathrm{H}\right]$-mibolerone can bind to progesterone receptor (as suggested by our competitive binding studies) the incubation is performed in the presence of a 1000 -fold molar excess of the synthetic (unlabelled) progestagen, ORG 2058; this binds specifically and with high affinity to progesterone receptor ${ }^{32}{ }^{33}$ without blocking androgen receptor binding, and prevents overestimation of androgen receptors in the presence of progesterone receptors. 
Unlabelled triamcinolone acetonide may be substituted for ORG 2058 to inhibit $\left[{ }^{3} \mathrm{H}\right]$-mibolerone binding to both progesterone receptors and glucocorticoid receptor. ${ }^{3435}$

Scatchard analysis of $\left[{ }^{3} \mathrm{H}\right]$-mibolerone binding confirmed the presence of high affinity androgen receptors protein $(\mathrm{Kd} 1 \mathrm{nmol} / \mathrm{l})$, with good correlations between the Scatchard analysis and isoelectric focusing assays.

"Crude" androgen receptor concentrations were significantly lower in TURP than in RPP samples of benign prostatic hyperplasia, a difference which disappeared when the androgen receptor concentration was "corrected" for epithelial cellularity. This new observation may reflect lower androgen receptor concentrations in TURP samples caused by heat inactivation of androgen receptors during electroresection, as shown by Gustafsson et al with progesterone receptors in experimental electroresection of prostatic tissue. ${ }^{36}$ Tissue sampling may be a factor causing these differences as RPP samples were often from the periphery of the gland, whereas TURP samples were from periurethral tissue. The central and peripheral zones of the prostate have very different structures, development, and hormone sensitivities ${ }^{37}$; the central zone responds more to maternal oestrogen stimulation in the uterus ${ }^{38}$ and to oestrogen in the mature gland ${ }^{39}$ than the peripheral zone, and prepubertal growth is also greater in this zone..$^{40}$ Thus the central zone, sampled during TURP, might be expected to contain lower androgen receptor concentrations than the peripheral zone. There is also more periglandular stroma in the central zone than in the periphery of the gland ${ }^{37}$; this proportionally reduces the epithelial content of the central zone, thereby increasing the "corrected" androgen receptor concentrations to concentrations similar to those of the peripheral gland.

Benign prostatic hyperplasia affects the periurethral and central zone of the prostate; prostatic carcinoma develops in the androgen sensitive peripheral zone of the gland. ${ }^{37}$ In benign prostatic hyperplasia TURP samples and "peripheral" samples of even larger RPP specimens consist predominantly of hypertrophied central zone prostatic tissue, and should, in theory, have similar hormonal sensitivity and hormone receptor concentrations.

In prostatic carcinoma TURP may remove normal or hyperplastic central zone tissue and peripheral zone tissue from which the carcinoma develops, but it is impossible to differentiate between these zones histologically in cryostat sections.

We believe that our observations on TURP and RPP samples in benign prostatic hyperplasia result from heat inactivation of androgen receptors during electroresection (TURP), and we recommend that
TURP specimens should not be used for the evaluation of androgen receptor concentrations in prostatic tissue. Upward "correction" of androgen receptor concentrations in TURP samples are probably an artefact resulting from zonal differences in the epithelial:stromal ratio in the prostate.

Our six confirmed prostatic adenocarcinomas showed a wide range of androgen receptor concentrations, probably resulting from a combination of real differences in androgen receptors between tumours and heat inactivation of androgen receptors during TURP. "Correction" for the variable epithelial cellularity did not affect the ranking of tumours with respect to androgen receptor concentrations, although one tumour became androgen receptor "positive". The validity of "correcting" tumour androgen receptor concentrations for epithelial cellularity is questionable, however, as it depends on the unlikely assumption that androgen receptors are present in epithelial but not stromal cells. If this asstumption is correct, or if androgen receptors are more concentrated in epithelial cells than in the stroma, then "corrected" androgen receptor concentrations may be more valuable than "crude" androgen receptor concentrations. Monoclonal antibodies to androgen receptors for immunolocalisation of androgen receptors in epithelial or stromal cells will be valuable in this context. Many more tumours must be assayed by this method, and the correlation between "corrected" androgen receptor values and response to endocrine manipulation in patients with prostatic adenocarcinoma must be evaluated before the validity of these "corrected" results and their clinical usefulness can be fully assessed. This type of assay may be of greater predictive value in determining the likely response to endocrine treatment than existing conventional biochemical androgen receptor assays.

This study was funded by the Special Trustees of the Former United Sheffield Hospitals and the Yorkshire Cancer Research Campaign, with contributions from ICI.

\section{References}

1 Huggins CB, Hodges CV. The effect of castration, of oestrogen and of androgen injection on serum phosphatases in metastatic carcinoma of the prostate. Cancer $\vec{R} \vec{e}$ 1941;1:293-7.

2 Buttýan R, Olsson CA. Androgen receptor assays in advanced prostatic cancer. Urol Clin North Am 1984;11:311-7.

3 Ekman P, Barrack ER, Walsh PC. Simultaneous measurement of progesterone and androgen receptors in human prostate: a microassay. J Clin Endocrinol Metab 1982;55:1089-99.

4 Schwartz MK. Relevance of steroid receptor measurements in the diagnosis and therapeutic management of cancer patients. In: Murphy GP, Sandberg AA, eds. Prostate cancer and hormone receptors. New York: Alan R Liss Inc, 1979:201-8.

5 Bruchovsky N. Rationale for the use of anti-hormone and drug combinations in the treatment of prostatic carcinoma. In: 
Schröder FH, ed. Androgens and antiandrogens. Weesp: Schering, 1983:35-47.

6 Ekman P. Clinical significance of steroid receptor assay in the human prostate. In: Schröder FH, de Voogt HT, eds. Steroid receptors, metabolism and prostatic cancer. Amsterdam: Excerpta Medica, 1980:208-34.

7 Trachtenberg J, Walsh PC. Correlation of prostatic nuclear androgen receptor content with duration of response and survival following hormonal therapy in advanced prostate cancer. $J$ Urol 1982;127:466-71.

8 Gustafsson J-A, Ekman P, Snochowski M, Zetterberg A, Pousette A, Hogberg B. Correlation between clinical response to hormone therapy and steroid receptor content in prostatic cancer. Cancer Res 1978;38:4345-8.

9 de Voogt HT, Dingjan PG. Is there a place for the assay of cytoplasmic steroid receptors in the endocrine management of prostatic cancer? In: Schröder FH, de Voogt HT, eds. Steroid receptors, metabolism and prostatic cancer. Amsterdam: Excerpta Medica, 1980;265-70.

10 Wagner RK, Schulze KH. Clinical relevance of androgen receptor in human prostate carcinoma. Acta Endrocrinol 1978; 215(Suppl): 139-40.

11 Olsson CA, de Vere White R, Goldstein I, Traish AM, Muller RE, Wotiz HH. A preliminary report on the measurement of cytosolic and nuclear prostatic tissue steroid receptors. In: Murphy GP, Sandberg AA, eds. Prostate cancer and hormone receptors. New York: Alan R Gliss Inc, 1979:209-21.

12 Bartsch G, Rohr HP. Endocrinological basis and clinical experience in conservative therapy in benign prostatic hyperplasia. In: Schröder FH, ed. Androgens and antiandrogens. Weesp: Schering, 1983:69-96.

13 Harper ME, Chaisiri P, Slade J, Peeling WB, Griffiths K. Prostate cancer. Hormonal relationships, receptors and tumour markers. Recent Results Cancer Res 1981;78:44-59.

14 Ekman P, Snochowski M, Dahlberg E, Bression D, Hogberg B, Gustafsson J-A. Steroid receptor content in cytosol from normal and hyperplastic human prostates. $J$ Clin Endocrinol Metab 1979;49:205-15.

15 Benson RC, Utz DC, Holicky E, Veneziale CM. Androgen receptor binding in human prostate cancer. Cancer 1985; 55:382-9.

16 Geller J, Albert J, Nachsheim D, Loza D, Lippman S. Steroid levels in cancer of the prostate-markers of tumour differentiation and adequacy of anti-androgen therapy. In: Murphy GP, Sandberg AA, eds. Prostate cancer and hormone receptors. New York: Alan R Liss Inc, 1979:103-11.

17 Bashirelahi N, Young JD, Sidh SM, Sanefuji H. Androgen, oestrogen and progestogen and their distribution in epithelial and stromal cells of human prostate. In: Schröder FH, de Voogt $\mathrm{HJ}$, eds. Steroid receptors, metabolism and prostatic cancer. Amsterdam: Excerpta Medica, 1980:240-55.

18 Ghanadian R, Auf G. Receptor proteins for androgens in benign prostatic hypertrophy and carcinoma of the prostate. In: Schröder FH, de Voogt HJ, eds. Steroid receptors, metabolism and prostatic cancer. Amsterdam: Excerpta Medica, 1980: 110-25.

19 Widdowson S, Ostrowski J, Dangerfield VJM, Parsons MA Ingleton PM. Underwood JCE. A novel prostatic androgen receptor assay with quantitative histology. $J$ Endocrinol 1986;108(Suppl):115.

20 Underwood JCE, Dangerfield VJM, Parsons MA. Oestrogen receptor assay of cryostat sections of human breast carcinoma with simultaneous quantitative histology. J Clin Pathol 1983;36:398-405.

21 Ironside JW, Battersby RDE, Dangerfield VJM, Parsons MA,
Timperley WR, Underwood JCE. Cryostat section assay of oestrogen and progesterone receptors in meningiomas: a clinicopathological study. J Clin Pathol 1986;39:44-50.

22 Auf G, Ghanadian R. Analysis of androgen receptors in the human prostate by isoelectric focusing in polyacrylamide gel. $J$ Steroid Biochem 1981;14:1261-7.

23 Randall VA, Mainwaring WP. Preliminary investigations of a new radioligand, ${ }^{3} \mathrm{H}$-Mibolerone for use in androgen receptor research. Proceedings of the 7th International Congress on Endocrinology. Amsterdam: Excerpta Medica: 1984:1199.

24 Akimoto S, Fuse H, Sato R, Zama S, Shimazaki J. Binding of mibolerone to androgen receptor of benign hypertrophic human prostate. Comparison with R1881. Endocrinol Japan 1985;32:141-52.

25 Bogan JA. Mibolerone. Drugs of Today 1979;15:34-7.

26 Bradford MM. A rapid and sensitive method for the quantitation of microgram quantities of protein utilizing the principle of protein-dye binding. Anal Biochem 1976;72:248-54.

27 Gustafsson J-A, Gustafsson SA, Nordenskjold B, Okret S, Silfversward C, Wrange $O$. Oestrogen receptor analysis in human breast cancer tissue with isoelectric focusing in polyacrylamide gel. Cancer Res 1978;38:4225-8.

28 Scatchard $G$. The attraction of protein for small molecules and ions. Ann NY Acad Sci 1949;51:660-70.

29 Chamness GC, McGuire WL. Scatchard plots: common errors in correction and interpretation. Steroids 1975;26:538-42.

30 Underwood JCE. A morphometric analysis of human breast carcinoma. B J Cancer 1972;26:234-7.

31 Hansson V, Larsen J, Reusch E. Physicochemical properties of the $5 \alpha$-dihydrotestosterone binding protein in human male serum. Steroids 1972;20:555-74.

32 Fleischmann G, Beato $M$. Characterisation of the progesterone receptor of rabbit uterus with the synthetic progestin 16 alphaethyl-21-hydroxy-19-norpregn-4-ene-3, 20 dione. Biochem Biophys Acta 1978;540:500-17.

33 Isomaa V. In vitro binding to and in vivo effect on the cytosol and nuclear receptors of various progestins and their relationship to synthesis of uteroglobulin in rabbit uterus. Biochem Biophys Acta 1981;675:9-16.

34 Asselin J, Mélançon R, Gourdeau Y, Labrie F, Bonne C, Raynaud JP. Specific binding of $\left[{ }^{3} \mathrm{H}\right]$-methyltrienolone to both progestin and androgen binding components in human benign prostatic hypertrophy (BPH). J Steroid Biochem 1979;10:483-6.

35 Bannister $P$, Sheridan $P$, Losowsky MS. Use of a new radioactive ligand, 7 alpha, 17 alpha-dimethyl [ 17 alpha methyl ${ }^{3} \mathrm{H}$ ] 19nortestosterone for the estimation of androgen receptors in rat liver cytosol. J Steroid Biochem 1985;23:121-3.

36 Gustafsson J-A, Ekman P, Pousette A, Snochowski M, Hogberg B. Demonstration of progesterone receptor in human benign prostatic hyperplasia and prostatic carcinoma. Invest Urol 1978;15:361-6.

37 Blacklock NJ. The development and morphology of the prostate. In: Ghanadian R, ed. The endocrinology of prostate tumours. Lancaster: MTP Press Ltd, 1983:1-13.

38 Andrews GS. The histology of the human foetal and pre-pubertal prostate. J Anat 1951;85:44-54.

39 Huggins C, Webster WO. Duality of the human prostate in response to oestrogens. J Urol 1948;59:258-66.

$40 \mathrm{McNeal}$ JE. The prostate and prosthetic urethra: a morphologic synthesis. J Urol 1972;107:1008-16.

Requests for reprints to: Dr M A Parsons, Department of Pathology, University of Sheffield Medical School, Beech Hill Road, Sheffield S10 2RX, England. 